Abstracta Iranicacta Iranica

Revue bibliographique pour le domaine irano-aryen

Volume 27 | 2006

Comptes rendus des publications de 2004

\title{
" Tea Consumption and Imports in Qajar Iran ». St. Ir., 33/1 (2004), pp. 47-111.
}

\section{Christoph Werner}

\section{(2) OpenEdition}

1 Journals

\section{Édition électronique}

URL : http://journals.openedition.org/abstractairanica/5951

DOI : 10.4000/abstractairanica.5951

ISSN : 1961-960X

Éditeur :

CNRS (UMR 7528 Mondes iraniens et indiens), Éditions de l'IFRI

\section{Édition imprimée}

Date de publication : 15 mai 2006

ISSN : 0240-8910

\section{Référence électronique}

Christoph Werner, « «Tea Consumption and Imports in Qajar Iran ». St. Ir., 33/1 (2004), pp. 47-111. », Abstracta Iranica [En ligne], Volume 27 | 2006, document 169, mis en ligne le 02 janvier 2007, consulté le 25 septembre 2020. URL : http://journals.openedition.org/abstractairanica/5951 ; DOI : https:// doi.org/10.4000/abstractairanica.5951

Ce document a été généré automatiquement le 25 septembre 2020.

Tous droits réservés 


\section{« Tea Consumption and Imports in Qajar Iran ». St. Ir., 33/1 (2004), pp. 47-111.}

\section{Christoph Werner}

1 Drinking tea in large quantities and on every occasion is so typical for present day Iran that one almost tends to forget that tea consumption is perhaps the country's most successful "invented tradition". Floor's bulky contribution on the topic could easily have been published in the form of separate articles and might be divided in two major parts. The first adds to our knowledge of the gradual spread of tea in the course of the nineteenth century and the development of a tea-culture in Iran, including the establishment of "coffeehouses". The second major part deals with the tea imports into Iran from the nineteenth to the early twentieth century. A discussion of major trade routes and ports of entry (Tabriz/Trabzon, Bushehr, Batoum/Ashkabad) is complemented by detailed statistics and tables, based on the British "Diplomatic and Consular Reports". Tea was also an object of commercial rivalry between Great Britain and Russia as the author demonstrates in his in-depth discussion of the effects of the 1903 new customs tariffs. Here, as in other instances, Floor's strength lies in collecting and presenting facts, while leaving it to others to elaborate further on his arguments and make use of the wealth of new material put together.

\section{INDEX}

Thèmes : 4.2.1. Safavides et Qâjârs 


\section{AUTEURS}

\section{CHRISTOPH WERNER}

Université de Freiburg im Brisbau 